\title{
Maintaining a sustainable workplace: Internal Corporate Social Responsibility practices in Dialog Semiconductor during the COVID-19 pandemic
}

Utrzymanie zrównoważonego miejsca pracy: Praktyki wewnętrznej społecznej odpowiedzialności biznesu w Dialog Semiconductor w czasie pandemii COVID-19

\section{Introduction}

During the coronavirus pandemic, a huge number of entrepreneurs have been facing difficulties in maintaining their organisation's performance, profitability, and employment. Some have changed how they operate; others have started to produce in-demand items like protective masks, disinfectants, or even parts for respirators, as well as hardware and software for measuring social distance. However, the most important issue for many leaders has been to ensure that their employees, or at least a substantial fraction of them, keep their jobs and salaries. Because we believe employees to be the key part of any organisation, we want to focus on internal aspects of Corporate Social Responsibility (CSR) and to show that activities undertaken in this field by the Dialog Semiconductor company have contributed significantly to the creation of a sustainable workplace in these uncertain conditions of the coronavirus pandemic. Firstly, we conduct a literature analysis to explain theoretical fundamentals such as the division between internal and external CSR, fields of internal CSR and the concept of a sustainable workplace. Then we look at the case of Dialog Semiconductor and discuss the ways in which their actions have influenced their ability to maintain a sustainable workplace. Finally, we provide insight into employees' feedback on the actions taken by the company leadership. The company was chosen due to an opportunity to conduct participant observation that is "a unique method for investigating the enormously rich, complex, conflictual, problematic, and 
diverse experiences, thoughts, feelings, and activities of human beings and the meanings of their existence" (Jorgensen, 2015). Another important factor in favour of choosing Dialog Semiconductor for this research is the fact that it is an international company and is present in many countries, therefore the case study could introduce the broader perspective of the pandemics' influence. The case study is based on three main sources of data: participant observation, an in-depth interview with Julie Pope, Senior Vice President, Human Resources at Dialog Semiconductor during the interview, and an analysis of Dialog Semiconductor's CSR reports. Finally, we provide insight into employees' feedback on the actions taken by the company leadership.

\section{Theoretical background}

\subsection{Workplace sustainability}

Building a sustainable workplace, in the simplest manner, requires providing the well-being of the employee, proper work environment and also well-being of the employee in the environment (Di Fabio \& Rosen, 2018). In the literature, workplace sustainability (WS) can be conceived either narrowly or broadly. In its narrow sense, WS is more technical and connected with resource management, and focuses on business practices that promote environmental sustainability and literary means creating a green workplace. In its broader sense, however, a sustainable workplace can be defined as "a positive workplace that has a contribution to improved work-life balance, employees' well-being, involvement in ethical and social decision-making, and develops awareness of being a part of the whole (community and the world)" (Samul, 2019).

Narrow WS requires a change in employee behaviour and the implementation of a number of technical solutions and tools for reducing energy waste and managing resources effectively (Greene et al., 2014; Moss, 2010). In environmental workplace sustainability, one key factor is organisation of a workplace that will be suitable to a particular kind of work. The growing importance of modern technologies and the role of knowledge workers as well as orientation on projects which requires team work result in changes in workspace design. A contemporary workplace has to provide a high level of autonomy but, at the same time, good conditions for interactions when needed (Harrison et al., 2004).

In order to build a sustainable workplace, employees are encouraged to adopt voluntary green workplace behaviour by motivational systems with material or 
non-material rewards. Metrics of environmentally friendly behaviours might also be included as components of performance appraisal, and organisational culture might be built on green values and contain internal policies supporting sustainable development (Saifulina \& Carballo-Penela, 2016). In some companies, in which green management is less developed, environmentally friendly behaviour is perceived as a kind of organisational citizenship behaviour (Wu et al., 2019). Social sustainability goes one step further, as within this concept, employees should help each other develop eco-friendly habits and, through sharing tacit knowledge, find new ways to implement eco-friendliness in their work routines (Paillé et al., 2018; Yuriev \& Sierra-Barón, 2020).

In our opinion, creating a green workplace can also be understood as a part of the broader meaning of WS because environmental workplace sustainability helps fulfil employees' needs. The office environment influences employees' well-being, by facilitating interaction among employees and providing good working conditions (Khusanova et al., 2019). Moreover, eco-friendly behaviours enable employees to feel like they are doing something good for the Earth as our common home. And when they are aware of their connection with the larger whole, people are more likely to participate in taking care of other people, the organisation, or the environment (Samul, 2019).

To get a full picture of the realisation of WS through internal CSR practices, it can be helpful to look at WS in its broader sense, including environmental WS. Before we can delve deeper, we need to understand the following key concepts used in the adapted definition: work-life balance, employee well-being, involvement in ethical and social decision-making, and awareness of being a part of the whole (community and the world).

People have to integrate their professional and private roles and set priorities for all the tasks they need to do. One definition of work-life balance states that it requires a supportive culture that enables employees to focus on their work while they are at work (Nasution \& Ali, 2020). Although this may appear to be a one-sided outlook that ignores the existence of private life, in reality, it leaves the time outside work free for the realisation of one's private roles. Disrupting the work-life balance can have serious consequences in both domains. When one devotes too much time to work, it can result in early burnout, marital breakdowns, child neglect, or poor social life (Marek, 2009). When employees use work time for dealing with private issues, they often neglect their duties, which can lead to negative performance appraisals or even termination. For these reasons, in a sustainable workplace, employees should experience harmony between those 
two areas of life, which allows them to minimise potential conflicts between personal and professional activities (Nasution \& Ali, 2020).

The simplest definition of employee well-being is "a sense of contentment that an employee feels when he/she is at work" (Anitha \& Shanthi, 2020). This also means being happy, healthy, safe, secure, and comfortable at work (Mitchel, 2018). Researchers enumerate the following six elements of employee well-being: a reasonably clear role in the organisation; personal control over one's job; a practicable workload; positive relationships at work; care from colleagues and supervisors; and a sense of control of involvement in changes in the organisation (Guest and Conway 2004). Looking at definitions of employee well-being might lead to the conclusion that employers are obliged to fulfil every whim of their employees, but these dimensions clarify needs strictly connected to the workplace. Employees need to have a clear understanding of their duties, be allowed to decide how to fulfil entrusted tasks, and be aware of their influence on the organisation's performance and on changes that are implemented in the organisation they work in. Moreover, they cannot be overloaded with work or denied support from colleagues and supervisors that builds healthy and positive relationships among them.

Both empowerment and employee participation are practical realisations of employee subjectivity (Marek, 2016). Empowerment consists of mutually related structural and psychological elements. The structural component can be understood as "a practice, or set of practices involving the delegation of responsibility down the hierarchy so as to give employees increased decision-making authority in respect to the execution of their primary work tasks" (Leach et al., 2003, p. 28). Psychological empowerment, on the other hand, serves to enable employees to take responsibility by fostering a sense of being competent and experienced, having autonomy in their work, and conducting meaningful tasks (Yu et al., 2018).

\subsection{Internal CSR}

Although the concept of CSR is well-known in the field of management among academics and practitioners alike, in most cases, research is focused on the general meaning of CSR and in the contexts of social, governmental, and environmental issues. However, there are some works addressing the internal practices of CSR itself (Papasolomou, 2017; Jamali et al., 2019; Mory et al., 2016), and this article is intended to contribute to this part of research. The reason internal CSR is less popular might lie in its lower visibility because the actions involve focusing on employees and owners, whereas external CSR increases brand popularity and positively influences a company's image. 
According to stakeholder theory, there are different groups of stakeholders, and a company should be managed for the benefit of all of them (Gouldey et al., 2016). Taking the boundaries of an organisation as a criterion, stakeholders can be divided into internal and external. Internal stakeholders - employees, the board of directors, owners, and trade unions - are directly affected by organisational goals and actions and take part in achieving stated aims of an organisation as well as in implementing of CSR practice itself (Haski-Leventhal et al., 2020; Hawn \& Ioannou, 2016). External stakeholders - customers, lenders, suppliers, and broader society (Freeman \& Reed, 1983), including the media, secondary schools, courts of law (Sznajder, 2013), competitors, third sectors, and the natural environment (Jastrzębska, 2015) - have no direct affiliation to a company but are somehow influenced by or interested in its actions and prosperity. On the basis of this division, academics distinguish between external and internal CSR. The former includes philanthropy and community contributions and is understood as ethical behaviour towards external stakeholders, while the latter encompasses ethical behaviour towards internal stakeholders, especially employees (Haski-Leventhal, 2018), and is concerned with their well-being and development (Haski-Leventhal et al., 2020).

It is necessary to recognise that a company cannot be considered a responsible business without providing favourable working conditions to its employees. Internal CSR practices must not be neglected in the course of pursuing external CSR goals (Hawn \& Ioannou, 2016). Academics emphasise the importance of "meeting the expectations of employees to be well treated when a company frames itself as internally responsible through obtaining a certificate of excellence" (Jamali et al., 2019). Furthermore, CSR actions in a company that practices philanthropy at the same time as it ignores the rights of employees may be perceived as hypocritical (Haski-Leventhal, 2018). Moreover, a lack of internal CSR activities might hinder the implementation of external ones, because under such circumstances, employees might oppose costly practices that create a positive image of a company which, in their opinion, is merely superficial because the company does not take care of its members. This is why we want to address - the often overlooked but no less important - internal CSR, which can be defined as "an organisational practice which represents how organisations engage in a socially responsible way towards their employees" (Mory et al., 2016, p. 1397).

There are several competing models accounting for what set of concepts should be included in an understanding of internal CSR. According to existing research results, it may consist of investment in human capital, health and safety, and management of change (European Commision, 2001); health and safety in the 
workplace, organisational justice and fairness, employee training and development, work-life balance (Papasolomou 2017); employment stability, skills development, workforce diversity, work-life balance, tangible employee involvement, and empowerment (Mory et al., 2016). Internal Labour Organisation (2020) provides a bit different perspective on CSR which focuses on dimensions of labour CSR. Three of these - freedom of association, non-discrimination, and health \& safety - are related to internal stakeholders whereas the fourth - the social monitoring of the supply chain - to external stakeholders (Abriata \& Delautre, 2020). For the purpose of this paper, we have adopted the division of Mory et al., as it is the most complex and detailed. Accordingly, we will understand employment stability as providing and securing stable jobs for employees; working environment as all issues connected to safety at work and health; skill development as all activities promoting individual skills of employees; workforce diversity as both promotion of gender equality and prevention of any kind of discrimination; work-life balance as ensuring proper balance between family life and professional duties; tangible employee involvement as decent income and fair share of the capital; empowerment as the level of employees' autonomy and their involvement in the decision-making process (Mory et al., 2016).

Internal CSR, which includes employee-friendly practices, is beneficial for a company. According to stakeholder theory, employees may view support for their welfare as a sign of the company's care and commitment to them and in turn put more energy and commitment into their work and engage in organisational citizenship behaviours. Additionally, dedicated employees might encourage others to seek positions with the company and portray their employer favourably. As a result, a company that takes care of its members retains highly qualified employees and attracts talented candidates (Liu \& Luo, 2019). These actions also increase employees' organisational identification and might be treated by employees as a sign of respect and recognition (Hameed et al., 2016).

Even if, under normal circumstances, employers operate sustainable workplaces, the COVID-19 pandemic has ruined existing harmony, requiring non-standard actions not only to maintain organisational functioning but also to restore harmony and to provide decent working conditions in a stressful situation. Both employees and employers during pandemic have to cope with restrictions influencing their work. Taking work home upsets the work-life balance and often requires using private tools and resources for professional purposes; relationships between employees weaken, and many people have to deal with loneliness, especially when work has been central to their lives. Many entrepreneurs are forced to close their businesses or at least to suspend activities 
for a prolonged period, facing a decision as to whether to lay off employees, lower remunerations, or to take out a loan to preserve everything at a constant level. As such, we will show that internal CSR can be helpful in providing sustainable working conditions for employees. For the purpose of the article we will compare elements of a sustainable workplace distinguished by Samul (2019) with the dimensions of internal CSR enumerated by Mory et al. (2016) which will enable us to show the influence of internal CSR activities on maintaining a sustainable workplace. We can notice that both concepts focus on creating working conditions that facilitate human potential development and respect the work-life balance. Elements such as employment stability, professional development, and tangible employee involvement might be successfully included in employee well-being, and workforce diversity can be conceived as including each and every one into community so it is creating the awareness of being a part of a larger whole. The problem is empowerment in CSR, which is a broader term than ethical and social decision-making in WS, as it also involves involvement in managerial decisions.

In light of both the similarities and differences between internal CSR and WS, we will present a case study of Dialog Semiconductor as an example of a company whose internal CSR actions helped in maintaining WS in the difficult time of the COVID-19 pandemic. We will also include actions specific to workplace sustainability that are focused on greening the organisation, which we perceive as an element of being a part of a larger whole.

\section{Internal Corporate Social Responsibility of Dialog Semiconductor}

\subsection{Company at a glance}

Dialog Semiconductor is a public limited company established in 1985 (Securities and Exchange Commission, 2003), with its corporate headquarters near London in Reading. The company operates more than 30 offices across 15 countries.

Dialog defines itself as "a fabless semiconductor company primarily focused on the development of highly-integrated and power-efficient mixed-signal Integrated Circuits ('ICs') for consumer electronics and high-growth segments of automotive and industrial end-markets." Its product portfolio includes a wide range of items of modern technology (Dialog Semiconductor, 2020). Annual sustainability reports illustrate Dialog's contribution to sustainable development. Initiatives taken by the company show that Dialog belongs to the group of responsible businesses. The key 
values, namely: agility, difference, many, ideas, encourage stakeholders to perceive Dialog Semiconductor as a highly modern, progressive company, oriented toward collaboration and excellence (Dialog Semiconductor, 2019).

\subsection{The process of implementing changes after the outbreak of the COVID-19 pandemic}

The onset of the COVID-19 pandemic required the introduction of special procedures for crisis management. The situation was changing constantly, and new circumstances forced the board of directors to place emphasis on the health and safety of Dialog Semiconductor's stakeholders - especially the employees who had to adjust to the new policies. the crucial element of introducing new procedures was clear, easily understood, constant communication within the company. The first thing Dialog did was for Senior Vice President for Human Resources Julie Pope (SVP HR) to send the entire workforce an email on 28 January 2020 clearly laying out the restrictions and rules the company was implementing. This would be the first of roughly weekly updates from the SVP HR. In addition, each particular team manager as well as the site operations managers have been giving the exact outlines for each employee due to the local pandemics situation and based on individual circumstances. This clear communication has been key to letting every individual in the company know what is expected of them and what the plan for ensuring their safety is. The whole process of introducing the changes to the working conditions, as illustrated in Figure 1, was integrated within the company and systematic. All these changes aimed to adjust to the "new normal" in the future.

Figure 1. The Path to "Reintegration"

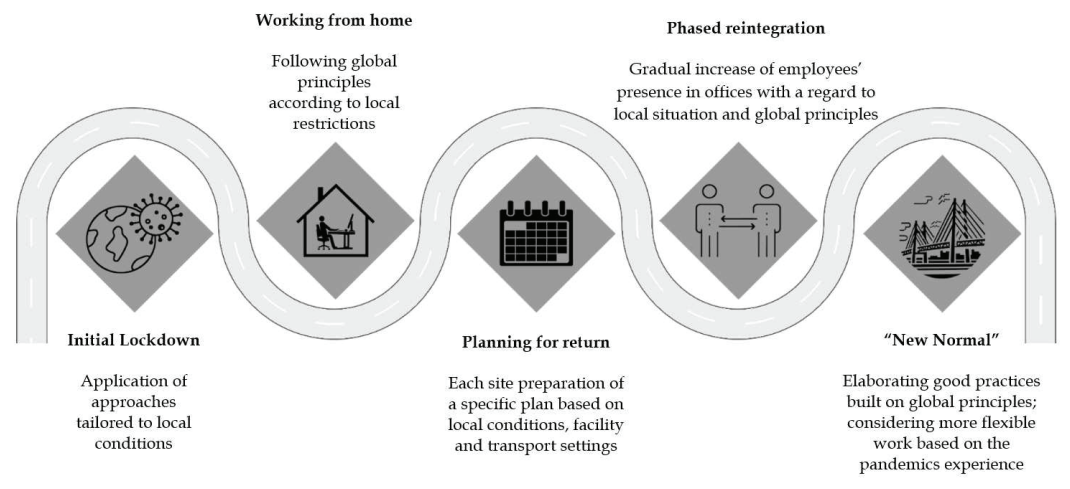

Source: Dialog Semiconductor. 
The company's main aim, and the main focus of all the actions taken in the framework of the internal CSR actions during the crisis, has been to keep all employees healthy and safe. Dialog was among the first companies in the industry that sent its workers to work from home. Decisions to lock down individual locations have been taken by the on-site leadership and the HR team in accordance with local government recommendations and other crucial sources of information (see Figure 2).

Dialog started preparing guidelines for managing employees' return to the offices at the end of April 2020. The SVP HR oversaw the overall process, and the strategy along with all the new initiatives were sent for final approvals to Chief Executive Officer Jalal Bagherli. This was to ensure that all the activities are consistent with other processes in the company - as sales, technical support and others. At the end of the day, the Dialog team created a whole set of reintegration guidelines to assist managers in decision-making processes. Five principles served as the basis for all decisions in all Dialog branches:

Figure 2. Sources of Information for Monitoring the Situation



Source: Dialog Semiconductor.

The primary value during the decision-making process is ensuring that each employee is as safe as possible under the circumstances. An individual approach has been taken to each employee, accounting for personal circum- 
stances and trying to be as flexible as necessary to make working from home safe and comfortable.

Not loosening restrictions sooner than the local legislation allows means that there is no rush to return people to offices; the situation has been constantly monitored to remain compliant with local legal frameworks.

Figure 3. Local Decisions in Accordance with Global Principles

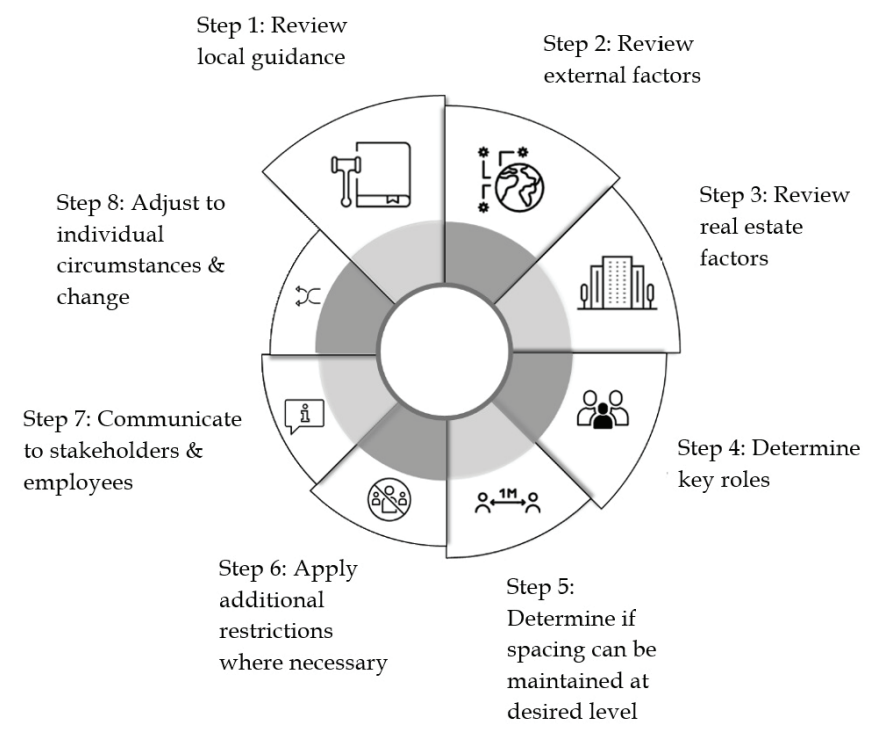

Source: Dialog Semiconductor.

All the employees were divided into four groups based on their need to have access to the office infrastructure. Employees whose jobs are the most difficult to perform from home could return first.

Adaptation to the continuous changes and response to them was the next principle. It gave a certain space for flexibility of decisions taken locally to preserve safety measures in response to the real situations in different countries. The framework of global guidance allows local differences. For example, in Asia, mandatory temperature screenings are common in many places, whereas in Europe this may be considered a violation of privacy.

Prior to the COVID-19 pandemic, Dialog had no strategy in place for managing such crises. When this crisis began, a dedicated, cross-functional team gathered data from the World Health Organisation and from local and national governments to monitor the constantly evolving information, assess its influence on the company, and develop guidance for its employees worldwide. 
During the lockdowns, Dialog took actions globally but with local variations. When the company started opening up, the process was the opposite - Dialog had global guidelines, but the decisions needed to be made locally. The reopening decision-making map is shown in Figure 3.

\subsection{Maintaining WS in Dialog Semiconductor by internal CSR actions}

\subsubsection{Work-life balance}

Normally Dialog strives to let its employees maintain healthy work-life balance by offering fair paid time off and free public holidays. Parental leave and leave for other special purposes are also available (Dialog Semiconductor, 2020). The COVID-19 crisis has upset the balance between work and private life, primarily by forcing employees to work from home. To make this easier, the IT team is supporting people in arranging their new remote work by providing helpful information on how to use the necessary tools and assisting with various technical issues. From the onset of quarantine restrictions, Dialog has had to deal with the hardships of employees whose children have to stay at home. The company offers flexible hours for parents who cannot work while taking care of children during school hours. Such employees may contact their managers to discuss options for shifting their working hours or working at weekends. Dialog is striving to be as supportive as possible and to assist all its employees in resolving any issues that they encounter during the pandemic.

\subsubsection{Employee well-being}

\subsubsection{Employment stability}

Employees are listed among the key sustainability priorities of the company. According to Dialog's 2019 report, employee turnover was $10 \%$, which is significantly below the industry standard $16.5 \%$ (Aon, 2019). It is also worth noting the low proportion of part-time employees - 3.4\% in 2018 and 3.3\% in 2019. The vast majority of employees have full-time contracts and a fair chance to develop their potential during a long-term career.

During the pandemic, there has not been any reduction in the number of employees or in their salaries. Moreover, the company has continued financing its operations exclusively using its own resources - no state support has been used to keep the company functioning. 


\subsubsection{Tangible employee involvement}

Dialog tries to reward its employees with regard to the best practices in the industry. Regular benchmarks are conducted to provide the employees with fair remuneration for their work (Dialog Semiconductor, 2019). That remuneration has not been cut in the wake of the pandemic. In fact, Dialog has introduced additional spending to let employees deal with their home office and commuting issues. The company has offered to cover up to \$400 USD of spending on tools that could make employees feel more comfortable when working from home. Additional financial support has been provided to those who have to commute to work by public transportation.

\subsubsection{Working environment}

The company stresses the importance of diversity and collaboration among its employees and in the external relations. Dialog's corporate culture supports inclusiveness, entrepreneurship, and a collaborative environment intended to let every employee fully develop their potential (Dialog Semiconductor, 2019). The working environment during the pandemic has been in constant flux in response to changing governmental restrictions and epidemiological information. The board or directors decided to introduce remote work for everyone who could work from home. To maintain standards of efficiency, employees have been allowed to take all necessary devices home, and the IT team has been tasked to assist in setting up home offices. Moreover, Dialog has also taken care of those who can work only in the company's premises. The technological profile of the company means that many engineers need huge machines to conduct experiments and test hardware. Dialog works with such employees to make sure that they are safe while at work. The top priority is to make sure that only a few people are in the offices, so those who need access to machines work shifts. Huge improvements have been introduced to health and safety procedures. All sites have adopted enhanced hygiene policies and begun providing employees with face masks and hand sanitiser. Social distancing measures were also implemented through increasing space between desks and limiting access to common areas like kitchens, conference rooms, etc. Mandatory temperature checks are conducted at reception. Elevators may be used only by a limited number of people. Because of the nature of the crisis, the company offered to assist any employee infected by COVID-19 with medical services or medications needed to fight the disease. These measures let the company be as flexible and prepared to guide each employee as possible. 


\subsubsection{Skills development}

Ongoing professional development is cited as a cornerstone of the long-term Dialog strategy, as the company considers its employees to be a critical component of its competitive advantage. Dialog invests in recruiting talented undergraduates and highly qualified experts while also providing development opportunities oriented on long-term careers (Dialog Semiconductor, 2019). In 2019, the "Emerging Leaders Programme" two-year development plan was introduced supporting the transition of leadership in the company. Dialog broadly cooperates with Mindtools - one of the world's leading online learning platforms - to provide employees with access to a variety of resources that enable employees to constantly improve their skills and develop themselves. Technical training for engineers is organised in the company. A mentoring programme is available to let workers share their experience in person. Dialog offers financial support for its employees to attend outside events and courses as well. Manager development programmes are another crucial part of corporate learning (Dialog Semiconductor, 2019). The company aims to educate every employee about how to perform their tasks ethically. As of 2019, 99\% of Dialog workers had completed online training devoted to preventing bribery, resolving conflicts of interest, protecting privacy, preventing harassment, and other crucial legal and ethical regulations (Dialog Semiconductor, 2019).

Adjusting to work in a crisis situation requires new ways of training employees. The company has started to promote more online courses and materials. The main source of learning information has been in the form of newsletters covering such topics as learning opportunities in Dialog, remote working, health and well-being, time and stress management, change management, mental health awareness, and collaboration. Some of the courses that the company would normally run in person - including leadership courses - are being conducted virtually. The overall learning process has been successfully maintained and adjusted to present needs.

\subsubsection{Involvement in ethical and social decision-making}

\subsubsection{Empowerment}

Although empowerment is broader than just decision making, they are tightly connected, so we decided to present empowerment activities as a part of the involvement in ethical and social decision-making element of WS. Dialog supports a few main forms of employee engagement including annual reviews, employee surveys, regular communications on the intranet, and individual and 
group meetings, all of which enable workers to get involved in sustainability activities and to get better acquainted with company strategy and learning and development opportunities. Because talented employees play key roles in both generating innovation and achieving success in business, Dialog focuses on improving the work environment and the terms of employment in order to increase employees' engagement and job satisfaction (Dialog Semiconductor, 2015-2019). In 2019, a director was appointed to take responsibility for employee engagement in collaboration with the HR team. Dialog measures the level of employees' engagement using the Global Engagement Survey. In 2019, 85\% of employees shared their feedback with the company by completing the survey. The results of the survey were sent to relevant departments and used to improve performance based on employees' opinions (Dialog Semiconductor, 2019).

During the COVID-19 crisis, Dialog has also involved employees in the whole process of making decisions. The overall policy also takes into consideration issues that are important to the employees. First of all, they can arrange their work themselves and discuss the best ways of adapting it to the new circumstances with their managers. They are allowed to work from home if they have to take care of their children or want to avoid commuting long distances. Additionally, all employees know that their business trips can be cancelled if they feel unsafe with going abroad, even if the country is not officially under quarantine.

Dialog's employees suggested a philanthropic activity in order to fight the pandemic. At the beginning of May, in response to employees' proposal, the company launched a gift matching programme. Every employee could decide to support one of the three selected organisations: Médecins Sans Frontières Coronavirus Crisis Appeal, the World Health Organisation COVID-19 Response Fund, and a Local or Global Red Cross / Red Crescent Charity. For one month, Dialog matched all confidential donations up to 100 USD to any of these organisations.

\subsubsection{Awareness of being a part of the whole}

\subsubsection{Workforce diversity}

In 2019, Dialog employed 2,036 permanent and 42 temporary employees, an increase of 459 from 2018 (1,073 in Europe, 585 in Asia, and 378 in the United States). Engineers represent $77 \%$ of the total workforce. Almost every fifth worker is female. The total number of women employed grew by $1.5 \%$ in comparison to 2018. The company is very international, employing people of 66 nationalities (Dialog Semiconductor, 2019). 
Dialog strives to create equal opportunities for all employees. The company raises awareness of career opportunities for women in engineering both inside and outside the company. Moreover, the company seeks to ensure equal representation of women; 25\% of the Board of Directors and 18\% of the Executive Team's are female. In partnership with the Women in Engineering Society (WES), in 2019, Dialog provided free memberships and access to WES events for the company's female managers and the HR team to develop their understanding of the importance of gender equality. In addition, Dialog monitors its remuneration policies to ensure that there is no discrimination based on gender (Dialog Semiconductor, 2019).

The company also stresses that its policy regarding equal treatment of disabled people provides special conditions of employment, learning, and career development processes that match their needs (Dialog Semiconductor, 2019).

As of June 2020, there have been no COVID-19 cases among Dialog employees. Nevertheless, a plan for the instance was introduced at the beginning of the pandemic. The case would be communicated anonymously, and all appropriate steps would be taken, including 14 days of quarantine for anyone who came into contact with the infected employee and a thorough disinfecting of the whole office. This way, the company would manage the infection whilst safeguarding the employee's privacy and protecting the person from any kind of discrimination.

\subsubsection{Employee feedback}

Dialog conducted anonymous research among its employees all around the world. The survey was launched twice, at the end of March and the end of May 2020. The aim of the research was to evaluate the company's response to COVID-19.

The survey was introduced online and sent to every employee, $69 \%$ of whom completed it. In the first three questions, employees were asked to rate each statement, and the fourth question included multiple choice options with an opportunity to choose two out of seven phrases. The survey included the following questions:

1) Well-being: Dialog is prioritizing the wellbeing of employees.

2) Decision: I feel Dialog is making good decisions in response to the situation.

3) Resources: I have the resources I need to do my job at this time.

4) Return Preparation (Pre-Return): What are your key priorities when considering returning to the workplace? Choose up to two options. Skip if you are currently in the workplace

- Staying healthy and safe in the workplace

- Safely commuting to work 
- The need to care for and protect family members

- Managing my workload

- I would prefer to continue working from home

- I have no concerns, I'm ready to be back in the workplace

- Other

Results show that workers were highly satisfied with the state of their corporate well-being ( $88 / 100$ points of the summed-up rating), decisions taken by managing persons (84/100 points of the summed-up rating) and they had enough resources to perform their job well (89/100 points of the summed-up rating). Each of the values were up three points in comparison to the March survey. This growth illustrates that the company improved its crisis management during the whole process and raised the satisfaction of Dialog employees.

Answers to the fourth question let the company understand what were the main concerns of its employees, $35 \%$ of whom declared that their priority is staying healthy and safe in the workplace. Twenty percent of employees stressed that they would prefer to continue to work from home even after reopening. Slightly under $20 \%$ of respondents stated that "the need to care for and protect family members" is their priority in preparing to return to the office. Almost $10 \%$ of employees identified "safely commuting to work" as their top priority. Other options were chosen much less frequently. All of these concerns were addressed by SVP HR during online meetings and in the e-mail correspondence.

\section{Conclusions}

When considering the CSR actions as well as the sustainable initiatives of Dialog Semiconductor, one should note that this paper is concentrated only on the aspects relevant to internal stakeholders, especially employees; we have not considered campaigns directed toward wider society or efforts to craft environmentally friendly products. In fact, Dialog does a lot more to be perceived as a responsible company in terms of sustainability and CSR in action.

Our research is a valuable contribution to literature on both workplace sustainability and internal CSR and shows business practices in a situation of crisis caused by COVID-19 pandemic. It has to be underlined that the case of the Dialog Semiconductor company that we have analysed is an example of a company that has not faced financial difficulties, as during COVID-19 pandemic, the IT sector has even increased its importance and income. Thus, maintaining WS has been relatively less difficult for companies in this space, allowing them to 
focus on the health and safety of employees, providing remote work conditions, and helping employees to function under the necessary restrictions. Further research is needed to draw a comparison with companies that had to close their facilities entirely and cease operations during this time.

\section{Bibliography}

Abriata, B., \& Delautre, G. (2020). What drives CSR? An empirical analysis on the labour dimensions of CSR. ILO Working Paper, 7. Geneva: ILO.

Anitha, K., \& Shanthi, V. (2020). Employee Well-Being - A Path to Redefine Workplace. Sumedha Journal of Management, 9(1), 79-90. doi: 10.46454/sumedha/9.1.2020.6 Aon. (2019). Retrieved from https://rewards.aon.com/enus/insights/infographics/2019/ technology/radford-turnover-hiring-sentiment-by-commercial-stage-at-u-s-based-life-sciences-companies-as-of (17.09.2020).

Di Fabio, A., \& Rosen, M.A. (2018). Opening the Black Box of Psychological Processes in the Science of Sustainable Development: A New Frontier. European Journal of Sustainable Development Research, 2(4), 47. doi: 10.20897/ejosdr/3933

Dialog Semiconductor. (2015). Sustainability report 2015. Retrieved from https:// www.dialog-semiconductor.com/sites/default/files/24371_dialog_sustainability_2015_int.pdf (10.01.2020).

Dialog Semiconductor. (2016). Always responsible. Sustainability report 2016. Retrieved from https://www.dialog-semiconductor.com/sites/default/files/dialog_sr_nav.pdf (29.12.2019).

Dialog Semiconductor. (2017). Focus on a sustainable business. Sustainability report 2017. Retrieved from https://www.dialog-semiconductor.com/sites/default/files/ dialog_sustainabilityreport_2017_interactivel.pdf (29.12.2019).

Dialog Semiconductor. (2018). Powering the smart connected future. Sustainability report 2018. Retrieved from https://www.dialog-semiconductor.com/sites/ default/files/sr_2018.pdf (10.01.2020).

Dialog Semiconductor. (2019). Building a power-efficient connected world. Annual report and accounts 2019. Retrieved from https://www.dialog-semiconductor. com/sites/default/files/gb0059822006-ja-2019-eq-e-00_0.pdf (14.01.2020).

Dialog Semiconductor. (2020). Retrieved from https://www.dialog-semiconductor.com/ (14.01.2020).

European Commision. (2001). Green Paper "Promoting a European framework for CSR”. Retrieved from https://ec.europa.eu/transparency/regdoc/rep/1/2001/ EN/1-2001-366-EN-1-0.Pdf (18.03.2020). 
Freeman, R.E., \& Reed, D.L. (1983). Stockholders and Stakeholders: A New Perspective on Corporate Governance. California Management Review, 25(3), 88-106. doi: $10.2307 / 41165018$

Gouldey B.K., Davis, M., Thies, C.F., Yavus, M. (2016). Stakeholder Theory and the Market Value Rule. Financial Decisions, 28(1), 1-20.

Greene, C., Crumbleholme, L., \& Myerson, J. (2014). Sustainable cultures. Facilities, 32(7/8), 438-454. doi: 10.1108/f-03-2013-0020

Guest, D. E., \& Conway, N. (2004). Employee well-being and the psychological contract: a report for the CIPD. London: Chartered Institute of Personnel and Development.

Hameed, I., Riaz, Z., Arain, G.A., \& Farooq, O. (2016). How Do Internal and External CSR Affect Employees' Organizational Identification? A Perspective from the Group Engagement Model. Frontiers in Psychology, 7, 1-13. doi: 10.3389/ fpsyg.2016.00788

Harrison, A., Wheeler, P., \& Whitehead, C. (2004). The distributed workplace: sustainable work environments. London-New York: Spon Press.

Haski-Leventhal, D. (2018). Strategic corporate social responsibility: tools \& theories for responsible management. London: SAGE Publications.

Haski-Leventhal, D., Roza, L., \& Brammer, S. (2020). Engagement of Employees in Corporate Social Responsibility. London: SAGE Publications.

Hawn, O., \& Ioannou, I. (2016). Mind the gap: The interplay between external and internal actions in the case of corporate social responsibility. Strategic Management Journal, 37(13), 2569-2588. doi: 10.1002/smj.2464

Jamali, D., Samara, G., Zollo, L., \& Ciappei, C. (2019). Is internal CSR really less impactful in individualist and masculine Cultures? A multilevel approach. Management Decision, 58(2), 362-375. doi: 10.1108/md-11-2018-1260

Jastrzębska, E. (2015). Środowisko przyrodnicze jako niemy interesariusz społecznie odpowiedzialnego przedsiębiorstwa. Dobre praktyki biznesu w Polsce. Logistyka Odzysku, 2(15), 49-51.

Khusanova, R., Choi, S. B., \& Kang, S.-W. (2019). Sustainable Workplace: The Moderating Role of Office Design on the Relationship between Psychological Empowerment and Organizational Citizenship Behaviour in Uzbekistan. Sustainability, 11(24), 7024, 1-20. doi: 10.3390/sul1247024

Leach, D.J., Wall, T.D., \& Jackson, P.R. (2003). The effect of empowerment on job knowledge: An empirical test involving operators of complex technology. Journal of Occupational and Organizational Psychology, 76(1), 27-52. doi: 10.1348/096317903321208871 
Liu, H., \& Luo, Jin-hui. (2019). Does a religious affiliation make the CEO more likely to use internal CSRs? Evidence from Chinese privately owned firms. The International Journal of Human Resource Management, 32(9), 1-33. doi: 10.108 0/09585192.2019.1602551

Marek, A. (2009). Work life balance and social capital - empirical research analyses. Conception of Work Life Balance and Personal Development Policy (p. 31-38). Łódź: Technical Univeristy of Lodz.

Marek, A. (2016). Employee Subjectivity as a Key Value in Management. Annales. Etyka w Życiu Gospodarczym, 19(4), 123-136. doi: 10.18778/1899-2226.19.4.09

Mitchel, D. (2018). 50 Top Tools for Employee Wellbeing: A Complete Toolkit for Developing Happy, Healthy, Productive and Engaged Employees [s. 1.]: Kogan Page Publishers.

Mory, L., Wirtz, B. W., \& Göttel, V. (2016). Factors of internal corporate social responsibility and the effect on organizational commitment. The International Journal of Human Resource Management, 27(13), 1393-1425. doi: 10.1080/09585192.2015.1072103

Moss, A. (2010). Sustainable Workplace Design. International Specialised Skills Institute, Retrieved from https://www.issinstitute.org.au/wp-content/uploads/2011/04/ ISS-FEL-REPORT-A-MOSS-low-res.pdf (27.04.2021).

Nasution, N., \& Ali, M. (2020). The Importance Of Work Life Balance To Improve Work Satisfaction. Jambura Science of Management, 2(2), 57-65. doi: 10.37479/jsm.v2i2.5410

Opatha, H. H. D. P. J. (2020). COVID-19 in Sri Lanka and Seven HRM Related Recommendations against COVID-19. Asian Journal of Social Sciences and Management Studies, 7(2), 152-157. doi: 10.20448/journal.500.2020.72.152.157

Paillé, P., Amara, N., \& Halilem, N. (2018). Greening the workplace through social sustainability among co-workers. Journal of Business Research, 89, 305-312. doi: 10.1016/j.jbusres.2017.12.044

Papasolomou, I. (2017). The Practice of Internal Corporate Social Responsibility in SMEs in Cyprus. In: S. Idowu, S. Vertigans, A. Schiopoiu Burlea (Eds.), Corporate Social Responsibility. CSR, Sustainability, Ethics \& Governance. Cham: Springer. doi: 10.1007/978-3-319-52839-7_5

Saifulina, N., \& Carballo-Penela, A. (2016). Promoting Sustainable Development at an Organizational Level: An Analysis of the Drivers of Workplace Environmentally Friendly Behaviour of Employees. Sustainable Development, 25(4), 299-310. doi: 10.1002/sd.1654

Samul, J. (2019). Spiritual Leadership: Meaning in the Sustainable Workplace. Sustainability, 12(1), 267. doi: 10.3390/su12010267

Securities and Exchange Commission. (2003). Retrieved from https://www.sec.gov/ Archives/edgar/data/1116581/000111658103000005/dlg20f02.htm (27.04.2021). 
Sznajder, M. (2013). Korzyści z wdrożenia koncepcji społecznej odpowiedzialności biznesu ( $\mathrm{z}$ uwzględnieniem koncepcji interesariuszy). Economics and Mangement, 5(2), 194-211.

Wu, P.-J., Wu, T.-J., \& Yuan, K.-S. (2019). “Green” Information Promotes Employees' Voluntary Green Behavior via Work Values and Perceived Accountability. Sustainability, 11(22), 6335. doi: 10.3390/su11226335

Yu, M., Vaagaasar, A. L., Müller, R., Wang, L., \& Zhu, F. (2018). Empowerment: The key to horizontal leadership in projects. International Journal of Project Management, 36(7), 992-1006. doi: 10.1016/j.ijproman.2018.04.003

Yuriev, A., \& Sierra-Barón, W. (2020). Exploring sustainability cross-culturally: Employees' beliefs on green behaviors. Sustainable Development, 28(5), 1199-1207. doi: 10.1002/sd.2069

\section{Summary}

The COVID-19 pandemic has presented the vast majority of companies with many difficulties in remaining efficient and profitable, especially whilst keeping their staff employed. In this article, we focus on the internal aspects of CSR - corporate social responsibility directed toward employees - and show that actions taken in this area at the Dialog Semiconductor company have significantly contributed to providing a sustainable workplace during the COVID-19 pandemic. Based on the theoretical fundamentals of the concept, this article illustrates the case study containing the activities taken and employee feedback. The results show that the company has successfully managed to maintain sustainable workplaces through actions coherent with the recommendations on HR (Human Resources) management in COVID-19 pandemic.

KEYwORDS: internal CSR, sustainable workplace, COVID-19.

\section{Streszczenie}

Pandemia COVID-19 pokazała, że wiele firm musiało zmierzyć się z trudnościami, aby mimo kryzysu, działać efektywnie a jednocześnie zminimalizować ryzyko redukcji kadry pracowniczej. Celem niniejszego artykułu jest ukazanie wpływu działań z zakresu wewnętrznego CSR podejmowanych przez Dialog Semiconductor, aby zapewnić zrównoważone miejsca pracy w czasie pandemii. Na bazie teoretycznych rozważań i analizy literatury prezentujemy studium przypadku zawierające szereg aktywności badanej organizacji oraz informację zwrotną od pracowników uzyskaną poprzez przeprowadzenie badań ankietowych. Wyniki przeprowadzonych badań wykazały, że przedsiębiorstwo z sukcesem utrzymało zrównoważone miejsca pracy w czasie pandemii stosując zalecenia i rekomendacje odpowiednich władz oraz dbając o swoich pracowników poprzez inicjatywy z zakresu wewnętrznej odpowiedzialności biznesu. 


\section{Noty o autorach}

Agnieszka Marek - Dr., Faculty of Social Sciences, Institute of Journalism and Management, The John Paul II Catholic University of Lublin; main fields: Management and Sociology; e-mail: agnieszka.marek@kul.pl; ORCID: 0000-0003-2803-1194.

Mariia Kozak - M.A., independent researcher; main fields: contemporary marketing tools, Big Data ethics, Corporate Social Responsibility; e-mail mary.kozak.bru@gmail.com; ORCID: 00000002-6283-1198. 
